\title{
Safety and Long-term Effects of Plasmapheresis
}

\author{
M. A. Cohen and H. A. Oberman \\ From the Department of Pathology, University of Michigan, \\ Ann Arbor, Michigan
}

No consistent clinical or laboratory value abnormalities were found during more than six years of plasmapheresis of donors who gave as much as the plasma equivalent of four units of whole blood per week. Potential hazards to the plasmapheresis donor, including hemoglobin depletion, protein depletion, iron depletion, and misidentification of blood returned to the donor are discussed. In addition to affording an economic and efficient opportunity to expand component therapy, repeated plasmapheresis of a small pool of preselected donors can provide a better quality product than that obtained from random donors.

INCREASED demand for plasma and plasma constituents in this country in recent years largely has been met by plasmapheresis. Although first introduced in 1914,1 and the subject of limited experimentation during World War $\mathrm{II}^{3}$ and in the early 1950's, ${ }^{4}$ the technic was not widely used until the advent of disposable closed plastic bag systems.

Plasmapheresis (aфaıperıs, withdrawal) is employed commercially to obtain plasma and plasma fractions, hyperimmune plasma, and antihemophilic factors. Within a hospital, the technic is useful for supplying platelets, white blood cells, and plasma coagulation factors, and also as a mode of therapy for Waldenström's macroglobulinemia,7,16 congestive heart failure, and acute hepatic failure. ${ }^{11}$

Previous reports have indicated the safety of plasmapheresis for the donor, and these have contributed to the exploitation of the technic. 5, 6.12,14, 15 Nevertheless, many persons have reservations concerning

Presented in part at the 1969 Annual Meeting of the American Society of Clinical Pathologists, September 17, 1969, Chicago, Ill.

Received for publication December 16, 1969; accepted January 26, 1970. possible harmful effects which might be induced by long-term intensive plasmapheresis. This report presents data accumulated during the collection of more than 14,000 units of plasma by plasmapheresis, during six years, from a relatively small group of donors in the Blood Bank of the University of Michigan Medical Center. Certain considerations germane to the operation of a plasmapheresis program in a hospital blood bank also are discussed.

\section{Materials and Methods}

Donors who participate in this program must fulfill the basic requirements established by the American Association of Blood Banks for all blood donors. They are predominantly medical or dental students, junior house staff, or paramedical personnel. All donors are men with large and accessible antecubital veins. Informed consent is obtained from all donors. Entrance to the program is contingent upon donation of five units of whole blood, or six units of plasma, followed by a six-month waiting period to ascertain whether the prospective donor may transmit hepatitis. Tests for irregular antibodies to red blood cells must be negative. Platelet donors understand that they may be called to donate any time of day or night.

Plasmapheresis is performed on an appointment basis. Donors with similar names are not scheduled to donate at the same time. The methods used in our blood bank for preparation of platelet-rich plasma, platelet concentrate, or AHG-cryoprecipitate have been described elsewhere. 13 When double plasmapheresis is performed, the first unit of packed red blood cells must be returned to the donor before the second unit of whole blood is collected. Approximately 60 to 75 minutes are required for removal of two units of plasma. The procedure may be repeated after 72 hours, so that the maximum rate of 

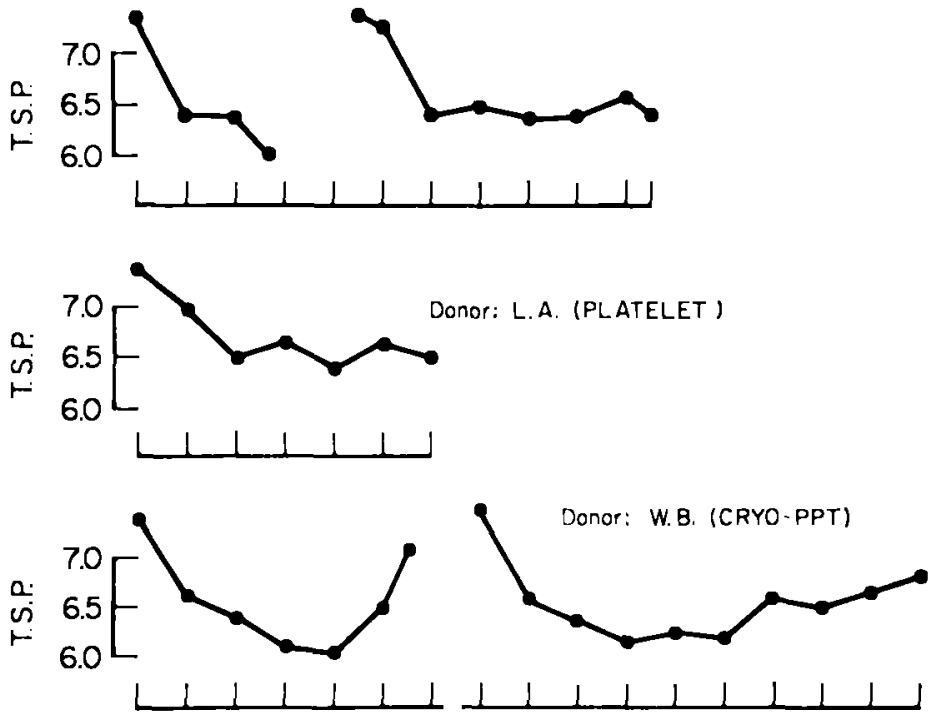

Fic. 1. Fluctuation of total serum protein levels in four donors during early months of intensive plasmapheresis. Values plotted represent monthly averages.

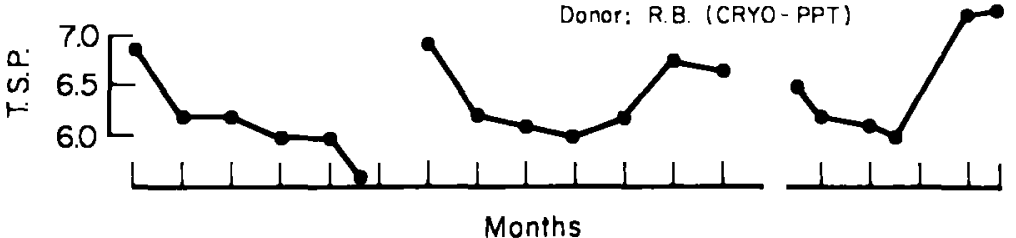

plasma removed is the plasma equivalent to that in four units of whole blood per week.

During plateletpheresis the platelet-rich plasma may be centrifuged a second time to prepare platelet concentrate, and the plateletpoor plasma then may be used to resuspend the packed red blood cells before they are returned to the donor. However, we find it efficient and economical for the blood bank to retain the unit of platelet-poor plasma for treatment of patients with hemophilia B or for volume expansion.

All donors in the cryoprecipitate program are type $A B$ and lack atypical antibodies, thereby obviating the need for a minor cross-match either for this product or the residual supernatant plasma. In addition, these donors must have and maintain Factor VIII activity in excess of 100 per cent as determined by the prothrombin activation rate. Factor VIII cryoprecipitate donors are expected to be available for at least one year after entering the program. The by-product from this procedure, AHG-poor type AB plasma is a safe and versatile product. 9
Studies performed on all donors in this study consisted of a donor history, total serum protein level (automated biuret method), hematocrit, and repeated tests for blood type and development of irregular erythrocyte antibodies with every plasma donation. In addition, at the initial donation and at every 20th double-plasmapheresis donation the following laboratory tests were performed: serum protein electrophoresis (cellulose acetate strips in barbital buffer, $\mathrm{pH}$ 8.6), serum iron and iron-binding capacity (sulfonated bathophenanthroline method), serum glutamic pyruvic transaminase (diazonium salt method), leukocyte count with differential, platelet count (hemocytometer), total serum bilirubin, serum hemoglobin (benzidene method), and serum cholesterol level (p-toluene sulfonic acid method). Quantitative immunoglobulins by radial diffusion and serum protein immunoelectrophoresis on agar-gel coated glass microscope slides were performed every 60th donation. The VDRL test for syphilis was performed at least once a month. 


\section{Results}

Since the plasmapheresis program for Factor VIII cryoprecipitate was initiated in 1963, more than 5,200 units of plasma have been collected. Eleven donors provided 4,500 of these units; moreover, four donors accounted for 2,550 of the units. The maximum donation by one subject (B. B.) was 931 units over four years. Although in 1963 several donors gave at rates up to 21 units per month, from 1964 to the present time the maximum rate of donation has been held to four units (two double-plasmapheresis procedures) per week. With the exception of infrequent brief "rests," all donors on this program have given at this rate for the duration of their participation.

The use of plasmapheresis as a source of platelets was instituted at the University of Michigan Medical Center in 1965. More than 8,600 units have been collected which account for 90 per cent of the platelets provided by the blood bank to the clinical services during this time. Although almost 170 donors have participated in the platelet plasmapheresis program, 15 donors have provided more than 2,300 units. The maximum donation by one subject in this program is 220 units in 2.5 years. The maximum rate of donation (four units per week) for the major duration of their participation in the program has been maintained by six donors.

\section{Serum Proteins}

Eighty-five per cent of donors manifested a decrease in total serum protein level of from 0.5 to $1.5 \mathrm{~g}$ per $100 \mathrm{ml}$ within one to three months after beginning plasmapheresis at the rate of four units per week (Fig. 1). Three donors, giving at this rate, did not exhibit this decline until up to seven months (or after donating 60 units) had elapsed. Seventy per cent of donors manifested this same decline within one to two months after resuming plasmapheresis following a rest period of from one to three months. Eight donors exhibited a spontaneous rise in their total serum protein to somewhat higher levels after the initial fall, but no donor's total serum protein level was as high as his preplasmapheresis level while donating at the rate of four units per week. Four of five donors who had donated at a submaximal rate for one or more months at the beginning of their program, manifested a decline in total serum proteins of the same magnitude, and in the same time, as those who donated at the rate of four units per week from the outset.
One donor (B. B.), early in 1963, gave 250 units of plasma in a ten-month period, during which time his average total serum protein level was $5.8 \mathrm{~g}$ per $100 \mathrm{ml}$. When donations were restricted to four units per week, his total serum protein level rose to an average of $6.5 \mathrm{~g}$ per $100 \mathrm{ml}$, and this level was maintained with but minor brief deviations for almost four years of plasmapheresis.

Whereas monthly averages of total serum protein levels, as demonstrated in Fig. I, illustrate the usual response to plasmapheresis, determinations performed at each donation (Table 1) indicate the inability of some donors to maintain serum protein levels greater than $6.0 \mathrm{~g}$ per $100 \mathrm{ml}$ without decreasing the frequency of donation.

Although peaks found by serum protein electrophoresis cannot be used to evaluate proteins accurately, all donors but one have had normal serum protein separations. Percentages of $\gamma$-globulin tended to be in the low range of normal for donors giving at the rate of four units of plasma each week (Table 2). One donor (J. W.) gave almost 100 units of plasma in six months, at which time his average total serum protein level fell to $5.8 \mathrm{~g}$ per $100 \mathrm{ml}$ and the $\gamma$-globulin to 5.3 per cent (300 mg per $100 \mathrm{ml}$ ). IgM and IgG levels were also low at that time. These values remained depressed during three additional months of plasmapheresis at the same rate, and did not return to normal until after three additional months of less frequent donation. Since that time his protein levels have been stable and he has provided more than 400 units of plasma (Fig. 2).

For all other donors, serum protein immunoelectrophoresis and immunoglobulin assays have revealed no consistent abnormalities resulting from plasmapheresis. Transferrin and ceruloplasmin arcs were present in every case. Quantitative immunoglobulin data are presented in Table 3.

\section{Hematologic Findings}

Fluctuations in the hematocrits of donors have not been observed. Leukocyte counts, differentials, and platelet counts have remained normal for all donors, regardless of the intensity or duration of plasmapheresis (Fig. 3). Similarly, leukocyte differential counts have been normal.

Serum hemoglobin levels have ranged from less than one to $49 \mathrm{mg}$ per $100 \mathrm{ml}$, with an average of $7.5 \mathrm{mg}$ per $100 \mathrm{ml}$ for 100 determinations on 16 random donors. This slightly 
TAвI. 1. Variation of Serial Total Serum Protein Levels in Four Plasmapheresis Donors

\begin{tabular}{|c|c|c|c|c|c|c|c|}
\hline & Date & $\begin{array}{c}\text { Units } \\
\text { Donated }\end{array}$ & $\begin{array}{c}\text { TSP } \\
(\mathrm{g} / 100 \mathrm{ml})\end{array}$ & & Date & $\begin{array}{c}\text { Units } \\
\text { Donated }\end{array}$ & $\begin{array}{c}\text { TSP } \\
(\mathrm{g} / 100 \mathrm{ml})\end{array}$ \\
\hline \multirow[t]{9}{*}{ Donor S.W. } & $7 / 15 / 67$ & 20 & 6.5 & Donor R.B. & $6 / 3 / 68$ & 80 & 7.5 \\
\hline & $7 / 18$ & 22 & 5.9 & & $6 / 5$ & 82 & 4.3 \\
\hline & $7 / 20$ & 24 & 4.1 & & $6 / 10$ & 84 & 5.8 \\
\hline & $8 / 1$ & 26 & 6.0 & & $6 / 12$ & 86 & 5.0 \\
\hline & $8 / 3$ & 28 & 5.8 & & $7 / 29$ & 88 & 6.9 \\
\hline & $8 / 8$ & 30 & 6.6 & & $8 / 14$ & 96 & 6.5 \\
\hline & & & & & $8 / 19$ & 98 & 5.8 \\
\hline & & & & & $8 / 21$ & 100 & 5.4 \\
\hline & & & & & $8 / 26$ & 102 & 6.1 \\
\hline \multirow[t]{9}{*}{ Donor J.H. } & $11 / 25 / 66$ & 74 & 6.1 & Danor J.W. & $11 / 2 / 66$ & 90 & 6.4 \\
\hline & $11 / 28$ & 76 & 5.7 & & $11 / 4$ & 92 & 5.4 \\
\hline & $12 / 1$ & 78 & 5.6 & & $11 / 9$ & 94 & 6.2 \\
\hline & $12 / 5$ & 80 & 6.3 & & $11 / 11$ & y6 & 5.5 \\
\hline & $12 / 7$ & 82 & 5.5 & & $11 / 15$ & 98 & 5.2 \\
\hline & $12 / 12$ & 84 & 4.7 & & $11 / 17$ & 100 & 5.2 \\
\hline & $12 / 16$ & 86 & 5.1 & & $11 / 22$ & 102 & 6.0 \\
\hline & $12 / 20$ & 88 & 6.2 & & $11 / 29$ & 104 & 6.3 \\
\hline & $12 / 27$ & 90 & 6.2 & & & & \\
\hline
\end{tabular}

elevated level is due presumably to hemoglobin released from red blood cells damaged during the process.

Levels of serum iron less than $50 \mathrm{mg}$ per $100 \mathrm{ml}$ were observed in three of the donors who gave plasma regularly at the rate of four units per week. However, in the absence of therapy or modification of frequency of donation, normal values subsequently were obtained in these men. Serum iron-binding capacities consistently were normal. No attempt to evaluate tissue stores of iron has been made. No donor has been given therapeutic iron, or advised to take iron.

\section{Liver Function Tests}

Greater than normal values of serum glutamic pyruvic transaminase were encountered in only one donor. That donor (B. B.) was hospitalized, after providing 781 units of plasma, for treatment of a peptic ulcer. At that time his SGPT rose to 45 units and his highest SGOT was 60 units. Sulfobromophthalein retention, alkaline phosphatase, bilirubin, and prothrombin levels were normal in this donor. Plasmapheresis was resumed after a threemonth rest and an additional 150 units of plasma were obtained in a nine-month period, during which time his SGPT consistently remained in the upper range of normal for our laboratory. Although all other liver-function tests were normal, the donor was dropped from the program because a barely palpable spleen was noted on physical examination. During the subsequent two years he has been in excellent health, and his spleen is no longer palpable.

Repeatedly elevated total serum bilirubin levels, 1.2 to $2.5 \mathrm{mg}$ per $100 \mathrm{ml}$, have been noted in three donors, none of whom has given plasma at the maximal rate. The sulfobromophthalein, SGPT, and alkaline phosphatase levels have been normal in these subjects. Nevertheless, two subjects were dropped from the program and $a$ third was permitted to resume plasmapheresis only after an eight-month rest, after which time his total serum bilirubin was $0.4 \mathrm{mg}$ per $100 \mathrm{ml}$.

One donor, giving at the rate of four units per week, consistently has had low-normal levels of serum. cholesterol, ranging between 140 and $150 \mathrm{mg}$ per $100 \mathrm{ml}$. Elevated levels of cholesterol have not been observed in any of the donors. 


\section{Additional Data}

Factor VIII levels have remained at abovenormal levels in all of the Factor VIII cryoprecipitate plasmapheresis donors. Direct questioning reveals no loss of exercise tolerance, appetite, or sexual libido, and no increased incidence of infection or minor respiratory illness in these donors. Some donors noted slight weight gain. With the exception of donor B. B., cited above, none has developed enlargement of liver, spleen, or lymph nodes.

\section{Discussion}

Inasmuch as all but approximately $2 \mathrm{ml}$ of the erythrocyte mass removed from each donor is returned, and consistent abnormalities in serum iron and hematocrit levels have not been observed, the physiologic limiting factor in plasmapheresis is the capacity of the donor to restore his plasma proteins. The normal adult human male replaces approximately $10 \mathrm{~g}$ of plasma albumin, and $2 \mathrm{~g}$ of plasma $\gamma$-globulin per day. ${ }^{10}$ Gamma-globulin, approximately half of the $\beta$-globulins, and a small fraction of the $\alpha$-globulins arise in lymphoid tissue; all other plasma proteins are of hepatic origin.10,17

Reversible depletion of plasma proteins is seen in the childhood nephrotic syndrome in which remission of the disease results in corresponding elevation of plasma proteins and replenishment of wasted tissue. Similar findings are seen with intensive plasmapheresis in the dog and in man. ${ }^{6,18}$

Andersen and Rossing ${ }^{2}$ observed an increased rate of synthesis and decreased rate of catabolism of albumin in one human subject undergoing intense plasmapheresis (30 units of plasma in one month). In this subject there was a shift of albumin from the interstitial to the vascular compartment, a decreased rate of $\gamma$-globulin catabolism, but no increased rate of synthesis of $\gamma$-globulin. During intensive plasmapheresis (five liters of plasma in five days in five human donors), Kliman et al. ${ }^{6}$ noted that up to $49 \mathrm{~g}$ protein was replaced per day; losses in excess of this amount were reflected in depression of total serum proteins to levels approximating $5.0 \mathrm{~g}$ per $100 \mathrm{ml}$. Recovery from such depletion may take from two to four weeks for albumin and total protein levels, but from one to three months for $\gamma$-globulin.

These data suggest that the liver is capable of responding to plasmapheresis by a fivefold increase in synthesis of albumin and other hepatic plasma proteins, but that the longer recovery for $\gamma$-globulin is dependent upon decreased catabolism. The persistence of transferrin and ceruloplasmin arcs, noted in this study, as well as the observation by Melin ${ }^{8}$ that the prothrombin complex and haptoglobin, also of hepatic origin, remain at normal levels further indicate the resistance to protein depletion at the rate of plasma withdrawal used in these donors.

When less than two liters of plasma are removed per week by plasmapheresis, significant depression of total serum proteins was not observed by Kliman et al.6 This generally is in accord with our findings. Although total serum protein levels in our donors fell to a slightly subnormal range for a short time, especially during the first six months of donation, for the ensuing period of long-term plasmapheresis total serum protein and $\gamma$-globulin was maintained at low-normal ranges. Nevertheless, individual variation in response to plasmapheresis, even at the rate of four units of plasma per week, is evident in the data presented. Some donors could not maintain normal levels of serum proteins at that rate, and required a longer interval between donations. For this reason, subjects undergoing a program of plasmapheresis should be monitored frequently by determining levels of total serum protein and protein fractions seen on electrophoresis.

Although plasmapheresis at the rate of four units per week usually does not result 


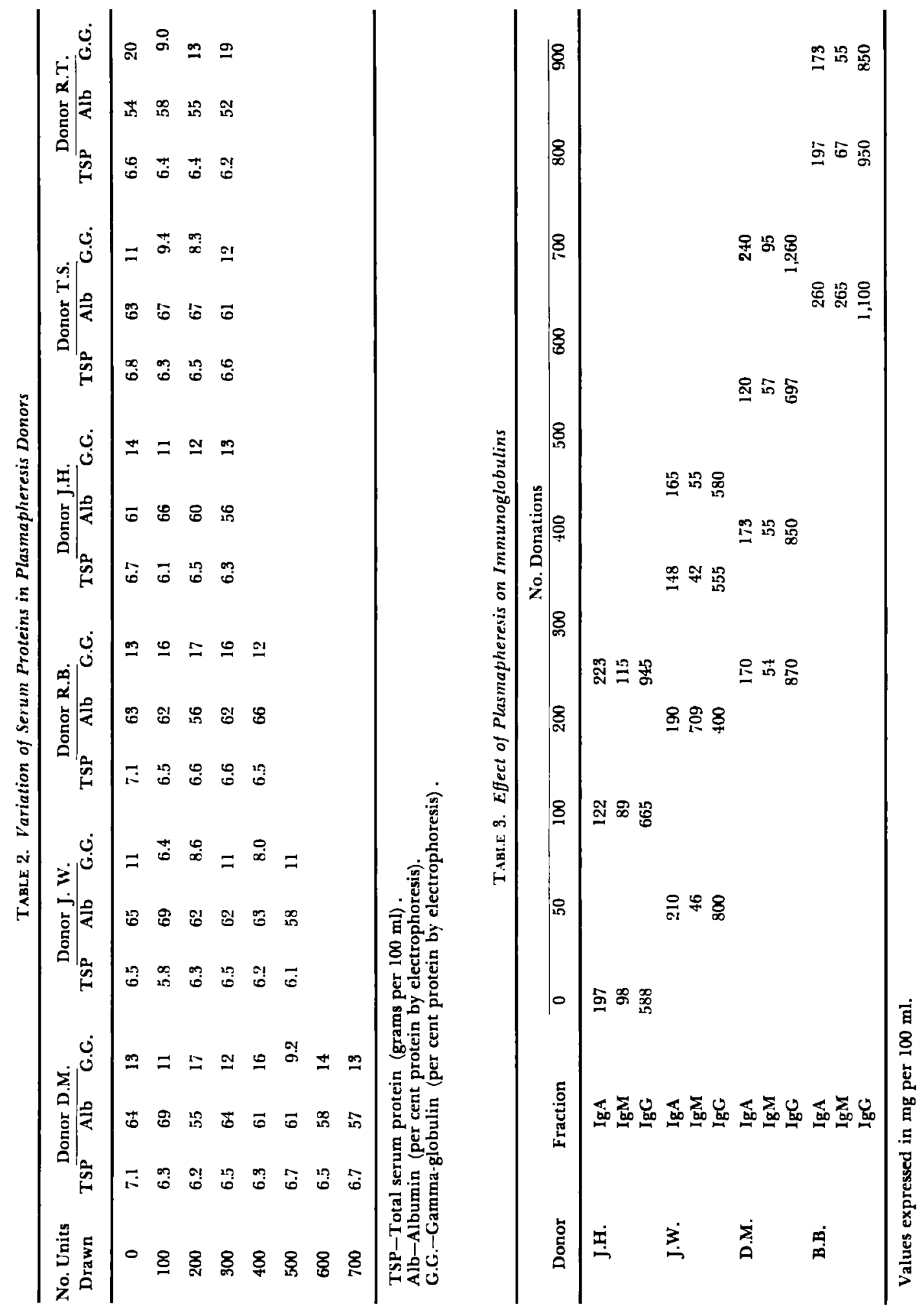




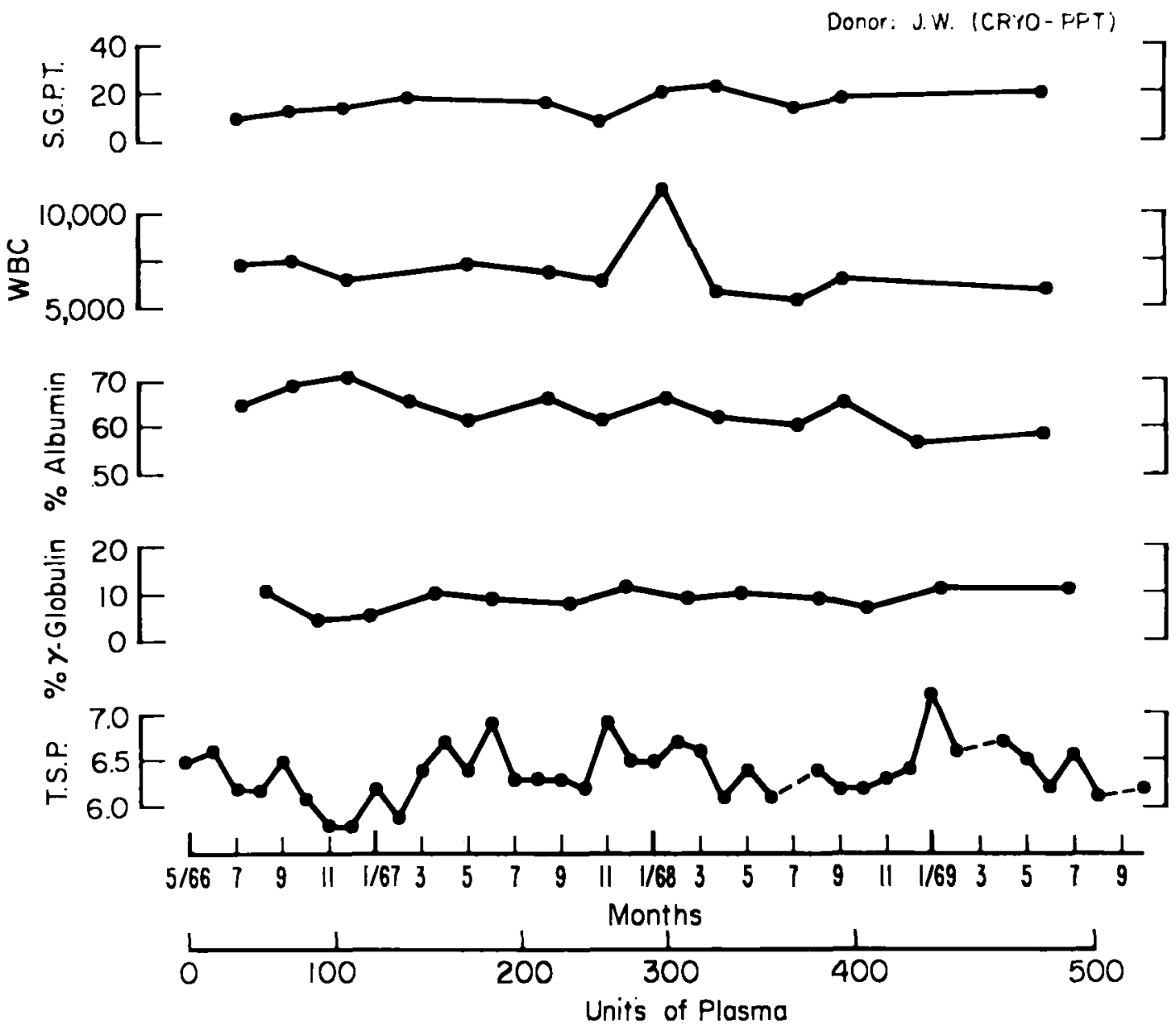

Fig. 2. Monthly determinations of serum glutamic pyruvic transaminasc; leukocyte count, total serum protein, per cent albumin and $\gamma$-globulin by scrum protein elcctrophoresis in a donor during 40 months of plasmapheresis.

in protein depletion, a 48-hour interval between donations of the plasma equivalent to two units of blood is the minimal time necessary for the restoration of plasma volume; we prefer to allow at least 72 hours. Whether performed for cryoprecipitate or platelets, plasmapheresis did not lower the leukocyte count or platelet count of donors.

Because a plasmapheresis donor may donate more than 200 units of plasma a year, his potential for transmitting hepatitis is 40 times greater than that of the whole- blood donor who is limited to five donations a year. It is for this reason that great care must be exercised in selecting donors for plasmapheresis programs. Use of a small group of prescreened donors thus provides the greatest safety possible to the recipient of these blood products.

Although the safety of plasmapheresis for the donor is apparent, many risks are involved, some recognized, others, perhaps, not yet known. For this reason informed consent from the donor, obtained by a physician, is mandatory. An individual 
about to enter the program should be in excellent health and have normal baseline laboratory values.

A protocol of laboratory studies for followings these clonors must be maintained. Moreover, a thorough donor history must be reviewed at each visit. On the basis of our experience, donors now providing plasma at the rate of four units per week are followed minimally with total serum protein and hematocrit values and screening for unexpected antibody at each donation, and bimonthly serologic test for syphilis and serum protein electrophoresis, serum glutamic pyruvic transaminase (SGPT) or the result of other tests for hepatitis detection, and leukocyte counts, leukocyte differentials, and platelet counts. If abnormal results are found, the patient is referred to an appropriate physician and corroborative tests are ordered. Otherwise, unexplained hypertransaminasemia is presumptive evidence of hepatitis, necessitating exclusion of the donor from the program.

Considerable loss of blood volume and hemoglobin results from removal of two units of blood during double plasmapheresis if, for technical reasons, the two units of red blood cells cannot be returned to the donors. Therefore we require that the second unit of blood be drawn only after the first unit of packed red blood cells has been reinfused successfully. Similarly, blood taken from the donor for laboratory studies may amount to as much as $1,500 \mathrm{ml}$ per year. If, in addition, the donor is permitted to donate five units of whole blood per year, up to $2.0 \mathrm{~g}$ iron may be lost. Despite enhanced absorption of dietary iron, iron loss at this rate results in depleted iron stores. Conservative withdrawal of blood for laboratory studies,
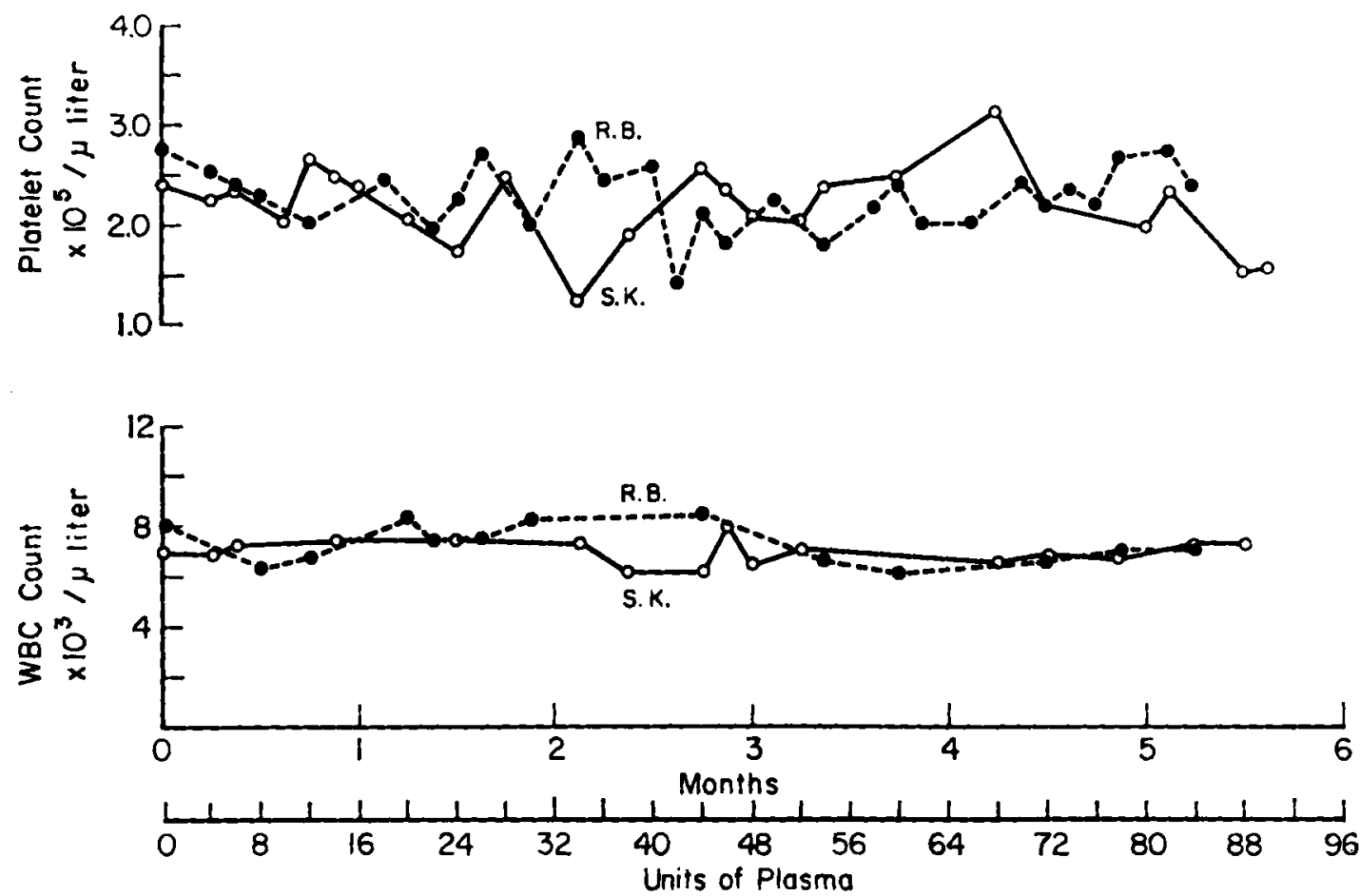

Fic. 3. Platelet and leukocyte counts in two donors during their initial six months of plasmapheresis. 
restriction of the donor pool to men, and permitting whole-blood donation on a submaximal schedule prevents depletion of tissue iron stores.

The greatest risk to the plasmapheresis donor is receiving the packed red blood cells of another donor. Despite this minimal risk to our type $\mathrm{AB}$ donors, they are acutely aware of the problem and actively join the technologist in proper identification of each bag. Only technologists or nurses who appreciate the seriousness of this step should be permitted to function in any plasmapheresis program. Undue levity and distraction in the donor room, especially among donors and technologists who are familiar through repeated visits, must not be permitted. Plasmapheresis donors are also susceptible to other reactions uniquely associated with the procedure, such as saline-induced diuresis and syncope due to rapid emptying of a distended urinary bladder. Because of these dangers, a physician must be available on the premises. Moreover, in therapeutic plasmapheresis in which sick patients are the "donors," it is especially important that a physician be present in the donor room during the procedure.

\section{References}

1. Abel, J. J., L. G. Rowntree, and B. B. Turner: Plasma removal with return of corpuscles (plasmapheresis). J. Pharmacol. Exp. Ther. 5: 625, 1914.

2. Andersen, S. B., and N. Rossing: Metabolism of albumin and gamma globulin during albumin infusions and during plasmapheresis. Scand. J. Clin. Lab. Invest. 20: 183, 1967.

3. Co Tui, F. C., F. C. Bartter, A. M. Wright, and $R$. B. Holt: Red cell re-infusion and the frequency of plasma donations: preliminary report of multiple donations in eight weeks by each of six donors. JAMA 124: 331, 1944.

4. Grifols-Lucas, J. A.: Use of plasmapheresis in blood donors. Brit. Med. J. 1: 854, 1952.

5. Kliman, A., and P. J. Schwab: Plasmapheresis with simple equipment. Amer. J. Clin. Path. 36: 379, 1961.
6. - P. P. Carbone, L. A. Gaydos, and E. J. Ireireich: Effects of intensive plasmapheresis on normal blood donors. Blood 23: 647, 1964.

7. Lawson, N. S., J. S. Nosanchuk, H. A. Oberman, and M. C. Meyers: Therapeutic plasmapheresis in treatment of patients with Waldenström's macroglobulinemia. Transfusion 8: $174,1968$.

8. Melin. M.: Conference on Plasmapheresis, 20th Scientific Meeting of Protein Foundation, Inc., Boston, Mass., April 7, 1966, pp. 78-79.

9. Oberman, H. A., and J. A. Penner: Utilization of the residual plasma following preparation of Factor VIII cryoprecipitate. JAMA 205: 819, 1968.

10. Peters, T.: The Biosynthesis of Serum Proteins. In Serum Proteins and the Dysproteinemias, F. W. Sunderman and F. W. Sunderman Jr., eds. Philadelphia, J. B. Lippincott Co., 1964, p. 9.

11. Sabin, S., and J. A. Merritt: Treatment of hepatic coma in cirrhosis by plasmapheresis and plasma infusion (plasma exchange). Ann. Intern. Med. 68: 1, 1968.

12. Simson, L. R., D. M. Lien, C. L. Warner, and H. A. Oberman: The long-term effects of repeated plasmapheresis. Amer. J. Clin. Path. 45: 367, 1966.

13. — , D. M. Lien, and H. A. Oberman: Plasmapheresis: an innovation in procurement of blood components. Mich. Med. 65: $111,1966$.

14. Smolens, J., J. Stokes, Jr., and A. B. Vogt: Human plasmapheresis and its effect on antibodies. J. Immun. 79: 434, 1957.

15. —- J. Stokes, Jr., E. McGee, and V. Hunter: Feasibility and safety of frequent plasmapheresis of the same human donors. Proc. Soc. Exp. Biol. Med. 91: 611, 1956.

16. Solomon, A., and J. L. Fahey: Plasmapheresis therapy in macroglobulinemia. Ann. Intern. Med. 58: 789, 1963.

17. Weissman, S. M., R. D. Wochner, F. X. Mullins, A. Wyngate, and T. A. Waldman: Synthesis of plasma proteins by hepatectomized dogs. Amer. J. Physiol. 210: 128, 1966.

18. Whipple, G. H.: Protein production and exchange in the body including hemoglobin, plasma protein and cell protein. Amer. J. Med. Sci. 196: 609, 1938.

Merrill A. Cohen, M.D., Resident IV, Department of Pathology.

Harold A. Oberman, M.D., I'rofessor, Department of Pathology, and Medical Director, Blood Bank, University of Michigan Medical Center, 1335 East Catherine Street, Ann Arbor, Michigan 48104. 